\title{
PENGARUH PENAMBAHAN LIMBAH SERBUK GIPSUM SEBAGAI BAHAN PENGGANTI FILLER PADA CAMPURAN ASPHALT CONCRETE-WEARING COURSE
}

\author{
Alimatul Hidayah ${ }^{1}$ dan Sugeng Dwi Hartantyo ${ }^{2}$ \\ ${ }^{1}$ Program Studi Sarjana Teknik Sipil Fakultas Teknik Universitas Islam Lamongan, Jl. Veteran No. 53A Lamongan \\ alimatul.hidayah99@gmail.com \\ ${ }^{2}$ Dosen Jurusan Fakultas Teknik Sipil Fakultas Teknik Universitas Islam Lamongan, J1. Veteran No. 53A Lamongan \\ sugeng.dwih@unisla.ac.id
}

Masuk: 09-07-2021, revisi: 28-07-2021, diterima untuk diterbitkan: 04-08-2021

\begin{abstract}
Gypsum waste is waste from the remnants of making gypsum lists that cannot be recycled and reused. In this study, gypsum powder was used as a filler substitute (cement). Where cement and gypsum powder waste contains high enough lime $(\mathrm{CaO})$. The aims of study are to determine how the process of making mixtures Aspal Concrete-Wearing Course $(A C-W C)$ by using gypsum powder waste as filler substitute (cement) and results of the Marshall test, namely stability, VFWA, VMA, VIM, Flow, and $M Q$ by using gypsum powder waste as filler substitute (cement).. The method used in this study is experimental method. Gypsum powder waste variation substitution 7\%, 8\% and 9\% shown the most ideal value of Marshall Properties are gypsum powder waste at 7\% variation with Marshall's highest parameter are Stability $870.95 \mathrm{Kg}$, VFWA 88.81\%, VMA 19.35\%, VIM 4.57\%, Flow $3.50 \mathrm{~mm}$ and Marshall Quotient (MQ) $252.72 \mathrm{Kg} / \mathrm{mm}$. The result that fulfill the criteria in the 2010 General Specification Divison .
\end{abstract}

Keywords : Filler; Gypsum Waste; AC-WC; Marshall Test

\begin{abstract}
ABSTRAK
Limbah Gypsum merupakan limbah dari sisa-sisa pembuatan list Gypsum yang tidak bisa di daur ulang dan di manfaatkan kembali. Pada penelitian ini limbah serbuk Gypsum digunakan sebagai bahan pengganti Filler. Dimana semen dan limbah serbuk Gypsum memiliki kandungan kapur $(\mathrm{CaO})$ yang cukup tinggi. Penelitian ini bertujuan untuk mengetahui bagaimana proses pembuatan campuran Aspal Concrete-Wearing Course (AC-WC) dengan menggunakan limbah serbuk Gypsum sebagai bahan pengganti Filler (semen) dan untuk mengetahui hasil pengujian marshall test yaitu stabilitas, VFWA, VMA, VIM, Flow dan MQ dengan menggunkan limbah serbuk Gypsum sebagai bahan pengganti Filler (semen). Metode yang digunakan pada ini adalah menggunakan metode eksperimen. Subtitusi variasi limbah serbuk Gypsum 7\%, 8\% dan 9\% menujukkan nilai Marshall Properties yang paling ideal yaitu limbah serbuk Gypsum pada variasi 7\% dengan parameter Marshall yang paling tinggi adalah Stability 870.95 Kg, VFWA 88.81\%, VMA 19.35\%, VIM 4.57\%, Flow $3.50 \mathrm{~mm}$ dan Marshall Quotient (MQ) $252.72 \mathrm{Kg} / \mathrm{mm}$. Hasil tersebut memenuhi kriteria dalam Spesifikasi Umum 2010 Divisi 6.
\end{abstract}

Kata kunci: Filler; Limbah Gipsum; AC-WC; Marshall Test

\section{PENDAHULUAN}

\section{Latar belakang}

Saat ini perkembangan penduduk di Indonesia sangatlah pesat. Seiring dengan hal tersebut dapat meningkatkan banyaknya kendaraan yang melintas di jalan raya. Seiring meningkatnya mobilitas yang sangat pesat maka perlu adanya peningkatan jalan raya dari segi kualitas maupun kuantitasnya (Subono, 2011). Perkerasan jalan merupakan bagian jalan yang diperkeras menggunakan lapis struktur dengan ketentuan ketebalan, kekakuan, serta stabilitas. Sehingga beban dari lalu lintas dapat disalurkan ke dasar jalan. Pada umumnya perkerasan lentur terdiri dari lapisan permukaan aspal diatas lapisan dasar dan lapisan dasar granular pada dasar jalan. Perkerasan jalan raya diletakkan berlapis-lapis, sehingga perkerasan tersebut mempunyai daya tahan dan daya dukung yang cukup, namun tetap ekonomis. Lapisan permukaan dibagi menjadi 4 lapisan yang meliputi Lapis permukaan (Surface Course), Lapis Pondasi Atas (Base Course), Lapis Pondasi Bawah (Subbase Course), Tanah Dasar (Subgrade).

Gipsum dalam keadaan murni dapat berupa Kristal memiliki warna putih, abu-abu, kuning, jingga atau hitam apabila tidak murni. Gypsum memiliki 2 macam yakni dehydrate (CaSO4 dan $2 \mathrm{H}_{2} \mathrm{O}$ serta air) dan andhirid (gypsum disuling 
dari 29,4\% zat kapur dan 23,5\% belerang). Gypsum berubah menjadi Basanit $\left(\mathrm{CaSO}_{4} \cdot \mathrm{H}_{2} \mathrm{O}\right)$ juga menjadi Andhirit $\left(\mathrm{CASO}_{4}\right)$ pada saat air panas, atau air yang memiliki kadar garam yang sangat tinggi. Pada suhu $108^{0} \mathrm{~F}$ atau $42^{\circ} \mathrm{C}$ dalam air murni akan menjadi Andhirid (Auditia \& Rendih, 2018)

Penggunaan limbah serbuk gipsum mampu menaikkan kualitas campuran perkerasan beraspal dimana limbah serbuk gipsum memiliki kandungan kapur $(\mathrm{CaO})$ yang cukup tinggi sehingga dapat digunakan sebagai bahan pengganti filler pada campuran perkerasan beraspal. Berdasarkan pada uraian diatas, peneliti akan melakukan penelitian mengenai penggantian bahan filler dengan menggunakan limbah serbuk gipsum. Tujuan dari penelitian ini adalah untuk mengetahui hasil pengujian marshall dan pengaruh penggunaan limbah serbuk gipsum pada campuran AC-WC.

Pada penelitan terdahulu yang telah dilakukan oleh Auditia, dkk (2018) dengan menggunakan metode Marshall yang mengacu pada SNI 2006- 2489-1991 untuk pengujian campuran perkerasan beraspal. Adapun Hasil dari pengujian campuran perkerasan aspal dengan kadar Gypsum 5\%, 6\%, 7\%,8\% dan 9\%, menunjukkan penambahan bubuk gypsum menjadi bahan pengganti bin 4 dalam campuran perkerasan beraspal mampu menaikkan kualitas campuran perkerasan beraspal pada kadar optimum, yakni pada kadar gypsum $6 \%$ dengan nilai density $2,12 \mathrm{gt} / \mathrm{cm}^{3}$, VIM 7,70\%, VMA 18,10\%, VFA 57,48\%, stability 4,8mm dan QM 321,96 (kg/mm).

Pada penelitian ini pengujian Marshall akan dilakukan secara bertahap sesuai tujuan penelitian untuk melihat hasilnya apakah kadar aspal yang digunakan telah memenuhi persyaratan atau tidak. Langkah selanjutnya adalah mengetahui pengaruh serbuk gipsum dalam campuran perkerasan terhadap nilai karakteristik Marshall yaitu (Marshall Stability), (Void Viled With Asphalt / VFWA), (Void In The Mix / VIM), (Void In Mineral Aggregate / VMA), (Flow), Dan Marshall Quotient (MQ)(Kementerian Pekerjaan Umum dan Perumahan Rakyat; Direktorat Jenderal Bina Marga, 2010)

\section{Asphalt Concrete - Wearing Course (AC - WC)}

Menurut Soehartono(2015), $A C$ - $W C$ merupakan lapis beton aspal yang digunakan untuk perkerasan jalan raya, mempunyai tebal sekitar $5 \mathrm{~cm}$ berfungsi sebagai lapisan aus maupun lapis penutup yang bersifat fleksibel untuk dapat menerima pergerakan lapisan dibawahnya tanpa mengakibatkan retak. $A C$ - $W C$ digunakan untuk lapisan permukaan dalam perkerasan yang mempunyai tekstur halus dibandingkan dengan jenis laston lainnya (Hasmiati \& Nurakhmad, 2014). Fungsi lapis aus adalah untuk melindungi perkerasan jalan daripengaruh air dan menyediakan permukaan yang halus serta kesat.

\section{Spesifikasi campuran Lataston}

Ketentuan sifat - sifat campuran lataston (Asphalt Concrete - Wearing Course) adalah pada Tabel 1.

Tabel 1. Persyaratan AC-WC untuk kepadatan lalu lintas

\begin{tabular}{ccc}
\hline No. & Spesifikasi & Nilai \\
\hline 1. & Pemadatan & $75 \times 2$ \\
\hline 2. & Density & - \\
\hline 3. & VIM & $3-5 \%$ \\
\hline 4. & VFWA & Min. $65 \%$ \\
\hline 5. & Stabilitas & Min. $800 \mathrm{Kg}$ \\
\hline 6. & Flow & $2-4 \mathrm{~mm}$ \\
\hline 7. & MQ & Min. $250 \mathrm{Kg} / \mathrm{mm}$ \\
\hline
\end{tabular}

Sumber:(Kementerian Pekerjaan Umum dan Perumahan Rakyat Direktorat Jenderal Bina Marga, 2010)

\section{Bahan penyusun perkerasan lentur}

\section{Aspal}

Aspal adalah material yang membentuk permukaan perkerasan lentur maupun perkerasan komposit. Aspal umumnya digunakan sebagai bahan pengikat yang berfungsi untuk menstabilkan lapisan pondasi. Aspal di dapatkan dari zat yang disaring dari minyak mentah yang hasilnya berwarna coklat tua hingga hitam pekat Agregat (Hardiyatmo, 2015).

\section{Agregat}

Agregat adalah komponen yang sangat berpengaruh pada lapisan perkerasan jalan yakni mengandung berat agregat 90-95\% atau volume agregat 75-85\%. Oleh karena itu, daya dukung, kualitas keawetan dan kualitas perkerasan juga ditentukan oleh sifat-sifat agregat (Hardiyatmo, 2015). Berdasarkan besar partikel agregat dibedakan atas: 
a. Agregat kasar

Agregat hasil disintegrasi alami batuan atau batuan pecah yang mempunyai ukuran 2,36 $\mathrm{mm}$ atau lolos saringan No. 8.

b. Agregat halus

Agregat hasil disintegrasi alami batuan atau batuan pecah yang mempunyai ukuran mm atau lolos saringan no. 8 atau tertahan saringan No. 200 (diameter $0.075 \mathrm{~mm}$ ).

3. Filler (bahan pengisi)

Menurut Hardiyatmo(2017). bahan pengisi (Filler) merupakan material berbulir sangat halus yang harus lolos pada saringan No.200 atau berukuran $0,75 \mathrm{~mm}$ harus dalam keadaan kering yang terdiri dari berbagai debu batu, kapur padam, semen porland, dan bahan non plastis lainnya.

\section{Limbah gipsum}

Gipsum adalah material yang umum dijumpai dan sering di manfaatkan sebagai hiasan interior rumah, gedung dan bangunan lainnya karena gypsum mudah dibentuk dan diaplikasikan dari pada bahan lainnya (Christanto \& Ibnu, 2005). Dalam bentuk murni, gypsum berupa Kristal yang memiliki warna abu-abu, putih, kuning, jingga ataupun berwarna hitam apabila tidak murni. Gypsum memiliki dua macam yakni dehydrate ( $\mathrm{CaSO} 4$ dan $2 \mathrm{H}_{2} \mathrm{O}$ serta air) pdan andhirid (gypsum disuling dari 29,4\% dari zat kapur dan 23,5\% dari belerang). Gypsum akan berubah menjadi Basanit $\left(\mathrm{CaSO}_{4} \cdot \mathrm{H}_{2} \mathrm{O}\right)$ dan akan menjadi Andhirit $\left(\mathrm{CASO}_{4}\right)$ jika air panas ataupun air yang memiliki kadar garam yang sangat tinggi. Pada suhu $108^{0} \mathrm{~F}$ atau $42^{\circ} \mathrm{C}$ dalam air murni berubah menjadi Andhirid (Auditia \& Rendih, 2018).

Nama kimia gypsum adalah Kalsium Sulfat Hidrat (CaSO4 2(H20)) sehingga material gypsum ini sangat dimungkinkan sebagai bahan filler dalam campuran beton aspal. Karena Gypsum memiliki komposisi kimia 23,28\% $\mathrm{Ca}, 2,34 \% \mathrm{H}, 37,57 \% \mathrm{CaO}, 20,39 \% \mathrm{H}_{2} \mathrm{O}, 18,63 \%$. Penggunaan serbuk Gypsum mampu meningkatkan nilai kualitas campuran perkerasan aspal menjadi lebih baik dari normal (Auditia \& Rendih, 2018).

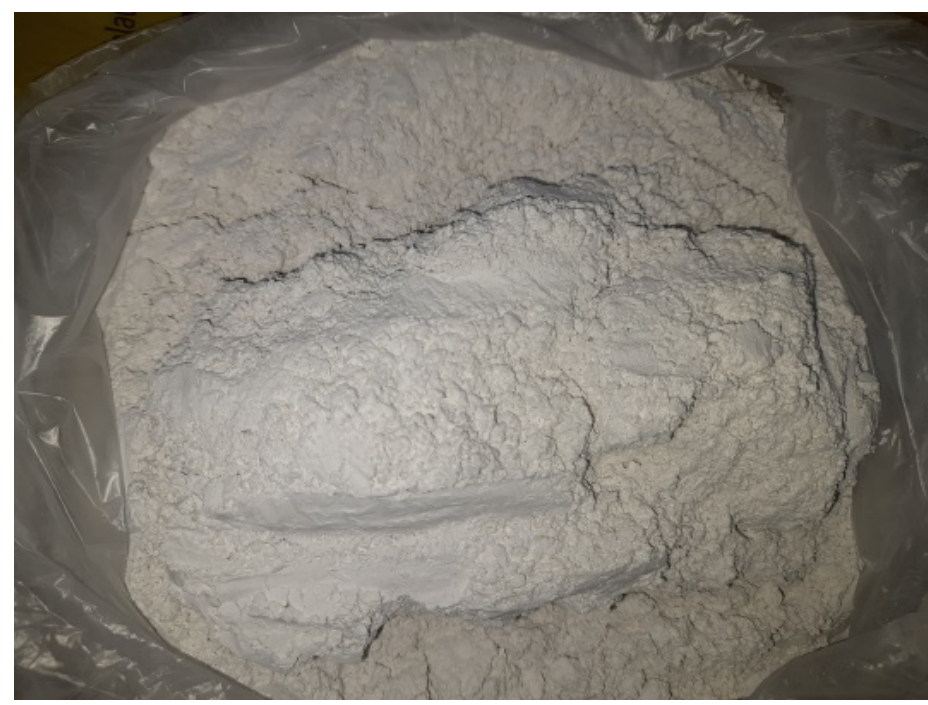

Gambar 1. Limbah serbuk gypsum

\section{METODE PENELITIAN}

\section{Lokasi dan waktu penelitian}

Penelitian ini telah di laksanakan pada tanggal 19 Februari 2021 dan berlokasi di Laboratorium Terpadu program studi teknik sipil Universitas Islam Lamongan

\section{Pengumpulan data}

Pada penelitian ini metode yang digunakan adalah metode eksperimental. Proses pengambilan data untuk penelitian ini dengan melalukan Mix Design untuk menentukan banyaknya jenis Filler yang akan digunakan sebagai bahan untuk pembuatan benda uji. Serta akan melakukan beberapa proses pemeriksaan agregat dan aspal. untuk memperoleh data - data yang diperlukan peneliti melaksanakan beberapa metode dalam pengumpulan data, yang mencangkup pengumpulan data primer maupun skunder pada saat penelitian berlangsung. 


\section{Data primer}

Data yang mengacu pada serangkaian percobaan, pengujian atau eksperimen yang dilakukan oleh peneliti dengan mengacu pada manual yang ada, seperti data yang diperoleh secara langsung atau dikumpulkan melalui pengujian atau inspeksi langsung.

\section{Data sekunder}

Data yang di dapatkan secara tidak langsung seperti dari jurnal atau artikel, buku, catatan, ataupun arsip baik yang telah dipublikasikan atau tidak di publikasikan secara umum.

\section{Tahap penelitian}

1. Tahap persiapan alat dan bahan

Peralatan yang digunakan:

a. Peralatan Pemeriksaan Agregat

Sieve analysis, piknometer, timbangan dan alat pemanas.

b. Peralatan Pemeriksaan Aspal

Alat uji penetrasi aspal, alat uji (titik lembek, titik nyala dan titik bakar aspal), serta alat untuk uji berat jenis (piknometer).

c. Satu set alat pengujian karakteristik campuran beraspal.

Bahan yang di gunakan pada penelitian ini :

a. Agregat halus

b. Agregat kasar

c. Filler (bahan pengisi) yang digantikan dengan menggunakan limbah serbuk gipsum

d. Aspal penetrasi 60/70

2. Pengujian bahan susun campuran AC-WC

a. Pengujian agregat

1) Pengujian berat jenis dan penyerapan air agregat halus

Pengujian ini bertujuan untuk menentukan berat jenis curah (bulk), berat jenis kering permukaan, berat jenis semu dan penyerapan air (SNI 1970-2008).

2) Pengujian berat jenis dan penyerapan air agregat kasar

Pengujian ini bertujuan untuk menentukan berat jenis curah (bulk), berat jenis kering permukaan, berat jenis semu dan penyerapan air (SNI 1969-2008).

b. Pengujian aspal

1) Pengujian penetrasi aspal

Pengujian penetrasi aspal bertujuan untuk mengetahui permeabilitas aspal, dengan cara memasukkan jarum penetrasi yang telah di tentukan ukuran, beban, waktu dan suhunya. Jika nilai penetrasi tinggi maka aspal akan semakin lemben dan sebaliknya jika nilai penetrasi aspal rendah maka aspal akan semakin mengeras. SNI 24562011.

2) Pengujian titik nyala dan titik bakar aspal

Pengujian ini bertujuan untuk mengetahui titik nyala dan titik bakar aspal. Titik nyala aspal adalah suhu nyala singkat apabila dilewatkan api penguji sedangkan Titik bakar aspal adalah suhu terlihat nyala dengan waktu kurang dari 5 detik diatas permukaan aspal. SNI 2433-2011.

3) Titik lembek

Pengujian ini bertujuan untuk menentukan titik lembek aspal yang berkisar antara $30^{\circ} \mathrm{C}$ hingga $200^{\circ} \mathrm{C}$ dengan cara bola baja terjatuh dan menyentuh pelat dasar bejana. SNI 2434-2011. 


\section{Job Mix Formula}

Perencanaan pencampuran (Job Mix) bertujuan untuk menentukan proporsi penggunaan bahan agregat kasar, agregat sedang, agregat halus dan Filler (bahan tambah gipsum) dalam pencampuran laston AC-WC.

4. Proses persiapan limbah serbuk gipsum

Limbah gipsum diambil dari home industry pembuatan list gipsum di kabupaten Lamongan. Kemudian limbah gipsum diolah dengan cara dihancurkan dan diayak menggunakan sieve shaker untuk mendapatkan serbuk yang lolos ayakan nomor 200 yang selanjutnya akan digunakan untuk bahan pengganti filler..

5. Metode pencampuran limbah serbuk gipsum

Metode pencampuran limbah serbuk gipsum yaitu dengan cara menimbang limbah sebuk gipsum, agregat kasar, agregat halus dan aspal yang telah di panaskan dengan suhu $150^{\circ} \mathrm{C}$ kemudian dicampurkan pada satu wadah dan dilanjutkan pada proses pengadukan selama \pm 20 menit. Setelah tercampur merata kemudian dipadatkan dengan menggunakan atat compact.

Komposisi bahan penyusun campuran aspal panas yang digunakan:

1. Agregat yang digunakan pada campuran AC-WC harus mengikuti spesifikasi SNI.

2. Aspal yang digunakan adalah penetrasi 60/70 yang merupakan produk pertamina.

3. Limbah gipsum didapatkan dari home industry pembuatan list gipsum di Lamongan.

4. Kadar aspal yang digunakan adalah sebesar 5,7\% dengan berat aspal.

5. Variasi campuran aspal panas dengan penggantian filler menggunakan limbah serbuk gipsum adalah 7\%, 8\%, dan $9 \%$ dari berat filler.

Tabel 2. Job Mix campuran $A C-W C$

\begin{tabular}{cccccccccc}
\hline \multirow{2}{*}{ Ayakan } & \multicolumn{2}{c}{ Agregat Halus } & \multicolumn{2}{c}{ Agregat Sedang } & \multicolumn{2}{c}{ Agregat Kasar } & Filler & Kombinasi & Spesifikasi \\
\cline { 2 - 8 } & $100 \%$ & $23 \%$ & $100 \%$ & $35 \%$ & $100 \%$ & $40 \%$ & $2 \%$ & Gradasi & 100 \\
\hline $3 / 4 "$ & 97,52 & 22,43 & 100 & 35 & 100 & 40 & 2 & 99,43 & $90 \sim 100$ \\
$1 / 2 "$ & 74,38 & 17,11 & 99,24 & 34,73 & 100 & 40 & 2 & 93,84 & $77 \sim 90$ \\
$3 / 8 "$ & 30,88 & 7,10 & 91,87 & 32,15 & 99,28 & 39,71 & 2 & 80,97 & $53 \sim 69$ \\
$\# 4$ & 8,87 & 2,04 & 33,13 & 11,60 & 98,04 & 39,22 & 2 & 54,85 & $33 \sim 53$ \\
$\# 8$ & 5,92 & 1,36 & 8,91 & 3,12 & 76,92 & 30,77 & 2 & 37,25 & $21 \sim 40$ \\
$\# 16$ & 5,74 & 1,32 & 6,88 & 2,41 & 44,95 & 17,98 & 2 & 23,71 & $14 \sim 30$ \\
$\# 30$ & 5,58 & 1,28 & 6,46 & 2,26 & 16,93 & 6,77 & 2 & 12,31 & $9 \sim 22$ \\
$\# 50$ & 5,45 & 1,25 & 5,84 & 2,04 & 7,50 & 3,00 & 2 & 8,30 & $6 \sim 15$ \\
$\# 100$ & 5,33 & 1,22 & 5,33 & 1,86 & 4,89 & 1,96 & 2 & 7,05 & $4 \sim 9$ \\
$\# 200$ & 5,21 & 1,20 & 4,75 & 1,66 & 4,72 & 1,89 & 2 & 6,75 & 4 \\
\hline
\end{tabular}

Dari hasil perhitungan Tabel Job Mix campuran AC-WC di peroleh hasil kombonasi antara agregat halus, agregat sedang, agregat kasar dan filler telah memenuhi spesifikasi.

6. Analisis pengujian marshall

Pengujian marshall test bertujuan untuk mengetahui pengaruh subtitusi limbah serbuk gipsum dalam campuran terhadap nilai marshall yaitu (Marshall Stability), (Void Viled With Asphalt / VFWA), (Void In The Mix / VIM), (Void In Mineral Aggregate /VMA), (Flow), Dan Marshall Quotient (MQ).

\section{HASIL DAN PEMBAHASAN}

\section{Hasil pengujian berat jenis dan penyerapan agregat}

Hasil pengujian material agregat Kasar, Sedang dan Halus ditunjukkan pada Tabel 3. 
Tabel 3. Hasil pengujian material agregat kasar, agregat, sedang dan agregat halus

\begin{tabular}{|c|c|c|c|c|}
\hline No & Jenis Pemeriksaan & Metode Pengujian & Hasil & Syarat \\
\hline \multicolumn{5}{|c|}{ Agregat kasar } \\
\hline 1 & Berat jenis curah (Bulk) & SNI 1969-2008 & 2,61 & $\geq 2,5$ \\
\hline 2 & Berat jenis kering permukaan & SNI 1969-2008 & 2,66 & $\geq 2,5$ \\
\hline 3 & Berat jenis semu & SNI 1969-2008 & 2,75 & $\geq 2,5$ \\
\hline 4 & Penyerapan air & SNI 1969-2008 & 1,93 & $\leq 2,5 \%$ \\
\hline \multicolumn{5}{|c|}{ Agregat sedang } \\
\hline 1 & Berat jenis curah (Bulk) & SNI 1969-2008 & 2,66 & $\geq 2,5$ \\
\hline 2 & Berat jenis kering permukaan & SNI 1969-2008 & 2,72 & $\geq 2,5$ \\
\hline 3 & Berat jenis semu & SNI 1969-2008 & 2,84 & $\geq 2,5$ \\
\hline 4 & Penyerapan air & SNI 1969-2008 & 2,40 & $\leq 2,5 \%$ \\
\hline \multicolumn{5}{|c|}{ Agregat halus } \\
\hline 1 & Berat jenis curah (Bulk) & SNI 1970-2008 & 2,57 & $\geq 2,5$ \\
\hline 2 & Berat jenis kering permukaan & SNI 1970-2008 & 2,65 & $\geq 2,5$ \\
\hline 3 & Berat jenis semu & SNI 1970-2008 & 2,87 & $\geq 2,5$ \\
\hline 4 & Penyerapan air & SNI 1970-2008 & 2,87 & $\leq 3 \%$ \\
\hline
\end{tabular}

Dilihat perhitungan pengujian material agregat kasar, agregat sedang dan agregat halus yang telah dilakukan oleh peneliti dengan hasil yang di peroleh adalah semua pengujian telah memenuhi persyaratan yang telah di tetapkan.

\section{Hasil pengujian aspal}

Hasil pengujian material aspal ditunjukkan pada Tabel 4.

Tabel 4. Hasil pengujian aspal

\begin{tabular}{cccccc}
\hline No. & Jenis Pemeriksaan & Metode Pengujian & \multicolumn{2}{c}{ Spesifikasi } & Hasil Pengujian \\
\hline & & & Min & Max & \\
\hline 1 & Penetrasi Aspal & SNI 2456-2011 & 60 & 70 & 67 \\
2 & Titik Nyala & SNI 2433-2011 & $200^{\circ} \mathrm{C}$ & - & $329^{\circ} \mathrm{C}$ \\
3 & Titik Bakar & SNI 2433-2011 & $300^{\circ} \mathrm{C}$ & - & $334^{\circ} \mathrm{C}$ \\
4 & Titik Lembek & SNI 2434-2011 & $48^{\circ} \mathrm{C}$ & $58^{\circ} \mathrm{C}$ & $53{ }^{\circ} \mathrm{C}$ \\
5 & Berat Jenis Aspal & SNI 2441-2011 & $\geq 1,00$ & - & 1,0209 \\
\hline
\end{tabular}

Dari Tabel pengujian aspal yang telah dilakukan oleh peneliti dengan hasil pengujian yang telah memenuhi persyaratan yang telah ditetapkan maka aspal layak untuk digunakan pada pengujian.

\section{Perhitungan kadar aspal rencana}

Untuk menghitung kadar aspal rencana yang akan digunakan untuk bahan campuran perkerasan diperoleh dari Persamaan (1).

$\mathrm{Pb}=0.035\left(_{\mathrm{CA}}\right)+0,045\left(_{\mathrm{FA}}\right)+0,18\left(_{\mathrm{F}}\right)+\mathrm{K}^{\cdots}$

$P \mathrm{~b}=0,035(12,50)+0,045(85,83+0,50)+0,18(2)+1$

dengan $\mathrm{CA}=$ Agregat kasar dengan nomor ayakan tertahan $8, \mathrm{FA}=$ agregat halus total melewati saringan nomor 8 dan tertahan nomor 200, $\mathrm{F}=$ Filler, $\mathrm{K}=$ Nilai konstanta

Jadi kadar aspal rencana yang akan digunakan dalam penelituan ini yaitu 5,7\%.

\section{Komposisi campuran aspal AC - WC}

Setelah melakukan perhitungan masing-masing agregat dan kadar aspal rencana, maka selanjutnya pembuatan komposisi masing-masing material dengan takaran kapasitas cetakan (mould) yang akan di gunakan untuk pengujian compact. Job Mix dari varian aspal AC-WC dengan limbah serbuk gipsum dapat dilihat pada Tabel 5. 
Tabel 5. Hasil pengujian aspal

\begin{tabular}{|c|c|c|c|c|c|c|c|c|}
\hline \multirow{2}{*}{$\begin{array}{l}\text { Kadar } \\
\text { Aspal }\end{array}$} & \multirow{2}{*}{$\begin{array}{c}\text { Kadar } \\
\text { Limbah } \\
\text { Serbuk } \\
\text { Gipsum }\end{array}$} & \multirow{2}{*}{$\begin{array}{c}\text { Berat } \\
\text { Serbuk } \\
\text { Gipsum }\end{array}$} & \multirow{2}{*}{$\begin{array}{l}\text { Berat } \\
\text { Aspal }\end{array}$} & $\begin{array}{c}\text { Agregat } \\
\text { Kasar }\end{array}$ & $\begin{array}{l}\text { Agregat } \\
\text { Sedang }\end{array}$ & $\begin{array}{c}\text { Agregat } \\
\text { Halus }\end{array}$ & Filler & \multirow[t]{2}{*}{ Total } \\
\hline & & & & $40 \%$ & $35 \%$ & $23 \%$ & $2 \%$ & \\
\hline$\%$ & $\%$ & $\mathrm{Gr}$ & & $\mathrm{Gr}$ & $\mathrm{Gr}$ & $\mathrm{Gr}$ & $\mathrm{Gr}$ & Gr \\
\hline 5,7 & 0 & 0,00 & 67,65 & 260,3 & 452,6 & 396,1 & 22,4 & 1200 \\
\hline 5,7 & 0 & 0,00 & 67,94 & 260,3 & 452,6 & 396,1 & 22,4 & 1200 \\
\hline 5,7 & 0 & 0,00 & 66,64 & 260,3 & 452,6 & 396,1 & 22,4 & 1200 \\
\hline 5,7 & 7 & 1,58 & 68,30 & 260,3 & 452,6 & 396,1 & 21,01 & 1200 \\
\hline 5,7 & 7 & 1,58 & 66,41 & 260,3 & 452,6 & 396,1 & 21,01 & 1200 \\
\hline 5,7 & 7 & 1,58 & 67,97 & 260,3 & 452,6 & 396,1 & 21,01 & 1200 \\
\hline 5,7 & 8 & 1,80 & 67,18 & 260,3 & 452,6 & 396,1 & 20,79 & 1200 \\
\hline 5,7 & 8 & 1,80 & 66,96 & 260,3 & 452,6 & 396,1 & 20,79 & 1200 \\
\hline 5,7 & 8 & 1,80 & 67,42 & 260,3 & 452,6 & 396,1 & 20,79 & 1200 \\
\hline 5,7 & 9 & 2,03 & 66,64 & 260,3 & 452,6 & 396,1 & 20,55 & 1200 \\
\hline 5,7 & 9 & 2,03 & 67,87 & 260,3 & 452,6 & 396,1 & 20,55 & 1200 \\
\hline 5,7 & 9 & 2,03 & 67,74 & 260,3 & 452,6 & 396,1 & 20,55 & 1200 \\
\hline
\end{tabular}

Dari Tabel JobMix varian aspal AC-WC dengan limbah serbuk gipsum diatas dibuat untuk satu kali cetakan dengan satu jenis varian sesuai dengan kebutuhan yang telah direncanakan. Kadar aspal yang digunakan yaitu sebesar 5,7\% dari berat aspal dan besarnya bahan limbah gipsum untuk pengganti filler yaitu sebesar $7 \%, 8 \%$ dan $9 \%$.

\section{Hasil pengujian Marshall Test}

Hasil pengujian Marshall Test aspal AC-WC dengan penggunaan limbah serbuk gipsum sebagai bahan pengganti filler dapat dilihat pada Tabel 6 .

Tabel 6. Hasil pengujian Marshall Test rata-rata dengan limbah serbuk gipsum sebagai pengganti filler

\begin{tabular}{cccccccc}
\hline (\%) & Stabilitas & VFWA & VMA & VIM & Density & Flow & MQ \\
\cline { 2 - 7 } Serbuk Gypsum & $(\mathrm{kg})$ & $(\%)$ & $(\%)$ & $(\%)$ & $(\mathrm{gr} / \mathrm{cc})$ & $(\mathrm{mm})$ & $\mathrm{kg} / \mathrm{mm}$ \\
\hline $0 \%$ & 813.76 & 86.40 & 19.75 & 5.04 & 2.40 & 3.27 & 253.41 \\
$7 \%$ & 870.95 & 88.81 & 19.35 & 4.57 & 2.41 & 3.50 & 252.72 \\
$8 \%$ & 790.88 & 72.19 & 22.89 & 8.76 & 2.30 & 3.67 & 224.98 \\
$9 \%$ & 768.98 & 66.35 & 24.84 & 11.06 & 2.24 & 5.33 & 164.49 \\
\hline \multirow{2}{*}{ Spesifikasi } & Min & Min & Min & $3-5 \%$ & - & $2-4 \mathrm{~mm}$ & $250 \mathrm{Kg} / \mathrm{m}$ \\
& $800 \mathrm{Kg}$ & $65 \%$ & $15 \%$ & & & & $\mathrm{~m}$ \\
\hline Pemadatan & & & $75 \times 2$ & & \\
\hline Kadar Aspal & & & $5,7 \%$ & & & \\
\hline
\end{tabular}

\section{Tinjauan penggantian limbah serbuk gipsum terhadap stabilitas}

Salah satu karakteristik marshall yaitu Stabilitas dimana pada perkerasan mempunyai kemampuan maksimum untuk menerima beban hingga mengalami kelelehan (Hartantyo \& Hermanto, 2019). Hasil pengujian stabilitas pada aspal AC-WC dengan penggunaan limbah serbuk gipsum sebagai bahan pengganti filler secara umum memperlihatkan peningkatan dan penurunan pada nilai stabilitasnya. Adapun hubungan antara stabilisat dengan limbah serbuk gipsum dapat dilihat pada Gambar 2. 


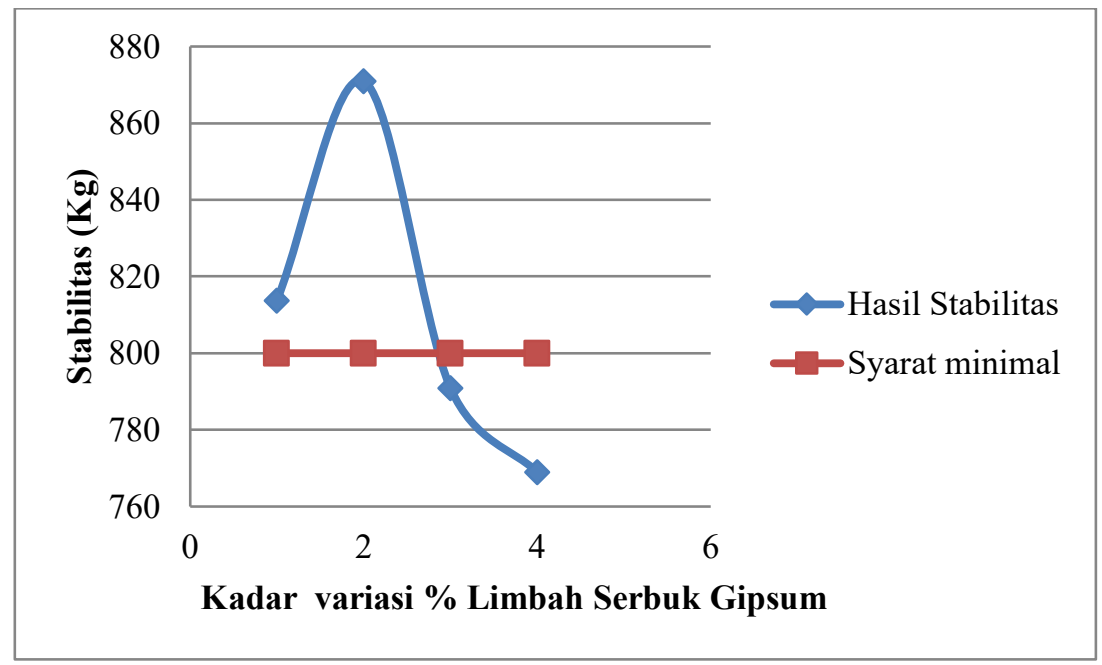

Gambar 2. Hubungan stability Mashall dengan limbah serbuk gypsum

Dari Gambar grafik diatas menunjukkan bahwa dengan penambahan limbah serbuk gipsum telah mempengaruhi nilai stabilitas nya dimana pada variasi $7 \%$ nilai stabilitas mengalami peningkatan sedangkan pada variasi $8 \%$ dan $9 \%$ nilai stabilitasnya mengalami penuunan. Berdasarkan ketentuan dan syarat nilai stabilitas minimal $800 \mathrm{Kg}$. sehingga stabilitas pada variasi limbah serbuk gipsum kadar 7\% telah memenuhi Standart Spesifikasi Umum Divisi 6 : Perkerasan Aspal. Sedangkan pada variasi limbah serbuk gipsum kadar 8\% dan 7\% titak memenuhi Standart Spesifikasi Umum Divisi 6 : Perkerasan Aspal karena menunjukkan menurunan hinggan dibawah $800 \mathrm{Kg}$.

Kadar limbah serbuk gypsum yang semakin rendah dapat mengakibatkan nilai stabilitas semakin meningkat sedangkan kadar limbah serbuk gypsum yang semakin tinggi menimbulkan penurunan pada nilai stabilitas namun penurunan yang terjadi tidaklah signifikan . hal ini dipengaruhi oleh beberapa faktor yaitu gesekan antara agregat, penguncian antara agregat dan kadar aspal yang digunakan juga sangat berpengaruh terhadap nilai stabilitas.

\section{Tinjauan penggantian limbah karbit terhadap Void in the minerale aggregate (VMA)}

Void In Minerale Agregate (VMA) adalah prosentase rongga dalam campuran pada perkerasan jalan. Hasil pengujian VMA pada aspal AC-WC dengan penggunaan limbah serbuk gipsum sebagai bahan pengganti filler secara umum memperlihatkan peningkatan dan penurunan pada nilai VMA. Adapun hubungan antara VMA dengan limbah serbuk gipsum dapat dilihat pada Gambar 3.

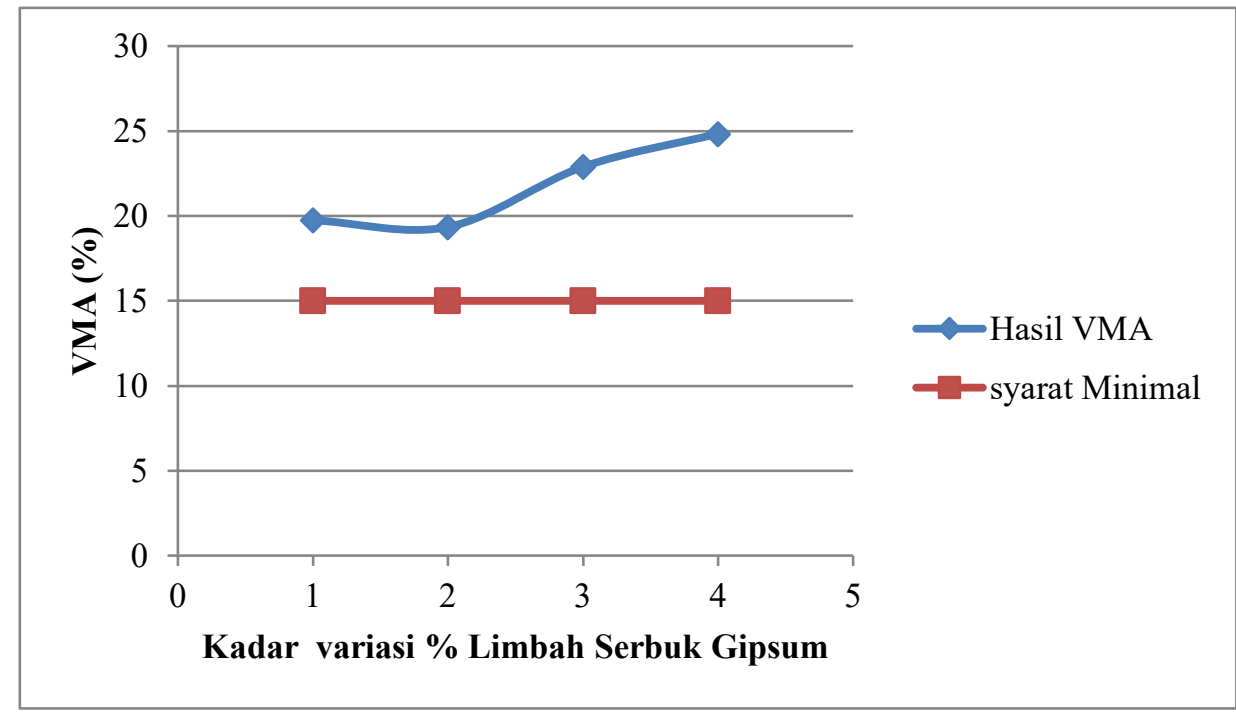

Gambar 3. Hubungan Void In Minerale Agregate (VMA) dengan limbah serbuk gypsum

Dari Gambar grafik diatas menunjukkan bahwa dengan penambahan limbah sebuk gipsum sebagai bahan pengganti filler telah mempengarui hasil dari VMA. Dimana pada variasi kadar limbah serbuk gipsum 9\% yaitu dengan nilai $24,85 \%$ mengalami peningkatan, namun terjadi penurunan pada variasi kadar limbah serbuk gipsum $7 \%$ dan $8 \%$ tetapi 
masih memenuhi ketentuan Standart Spesifikasi Umum Divisi 6 : Perkerasan Aspal dimana nilai VMA miniman 15\%. Sehinggan semua variasi limbah serbuk gypsum 7\%, 8\% dan 9\% telah memenuhi ketentuan Standart Spesifikasi Umum Divisi 6 : Perkerasan Aspal .

Nilai VMA berpengaruh pada sifat keawetan dan kekedapan terhadap udara dan air. Adapun faktor yang mempengaruhi VMA adalah banyaknya jumlah tumbukan, kadar aspal dan gradasi agregat pada campuran. Semakin tinggi nilai VMA maka semakin banyak rongga pada campuran yang terisi aspal sehingga kekedapan terhadap air dan udara semakin tinggi, namun bila nilai VMA terlalu tinggi maka dapat mengakibatkan bleeding pada perkerasan jika menerima beban pada temperature yang tinggi. Sebaliknya jika nilai VMA terlalu kecil maka dapat mengakibatkan terjadinya stripping pada perkerasan.

\section{Tinjauan penambahan limbah karbit terhadap Voids Filled With Asphalt (VFWA)}

Void Filled With Asphalt (VFWA) adalah prosentase rongga campuran yang terisi aspal yang terdapat di antara pertikel agregat (VMA) yang terisi oleh aspal. Hasil pengujian VFWA pada aspal AC-WC dengan penggunaan limbah serbuk gipsum sebagai bahan pengganti filler secara umum memperlihatkan peningkatan dan penurunan pada nilai vfwa. Adapun hubungan antara VFWA dengan limbah serbuk gipsum dapat dilihat pada Gambar 4.

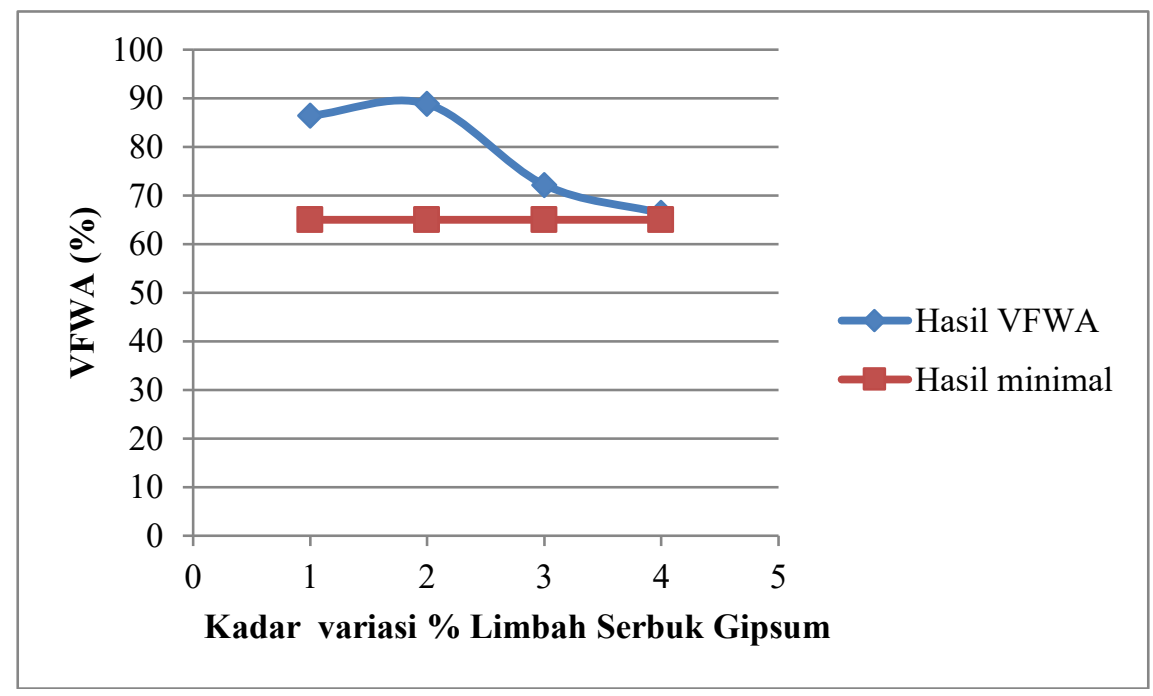

Gambar 4. Hubungan (VFWA) dengan limbah serbuk gypsum

Dari Gambar grafik diatas menunjukkan bahwa dengan penambahan limbah sebuk gipsum sebagai bahan pengganti filler mempengarui hasil dari VFWA. Dimana semakin banyak bertambahnya variasi kadar limbah serbuk gipsum maka semakin menurun pula nilai VFWA. Dari data diatas penngkatan VFWA tertinggi terdapat pada variasi kadar limbah serbuk gipsum 7\% yaitu dengan nilai 88,81\%, sedangkan pada variasi yang lebih besar nilai VFWA mengalami penurunan pada variasi kadar limbah serbuk gipsum 9\% yaitu dengan nilai 66,35\%, meskipun mengalami penurunan akan tetapi masih memenuhi ketentuan Standart Spesifikasi Umum Divisi 6 : Perkerasan Aspal yaitu minimal 65\%.

Nilai VFWA dapat meningkatkan keawetan campuran, nilai VFWA yang terlalu besar dapat mengakibatkan terjadinya bleeding pada saat temperature tinggi sehingga ketika perkerasan menerima beban aspal dapat naik kepermukaan. Namun jika nilai VFWA terlalu kecil maka akan dapat mengakibatkan kekedapapan campuran semakin kecil dan aspal pada campuran akan terosidasi dengan udara yang mengakibatkan berkurangnya keawetan perkerasan.

\section{Tinjauan penggunaan limbah karbit terhadap Void in the mix (VIM)}

Void In The Mix (VIM) merupakan Rongga udara pada campuran perkerasan yang terdiri dari ruang udara antara partikel agregat yang terselimuti aspal. Hasil pengujian VIM pada aspal AC-WC dengan penggunaan limbah serbuk gipsum sebagai bahan pengganti filler secara umum memperlihatkan peningkatan dan penurunan pada nilai VIM. Adapun hubungan antara VIM dengan limbah serbuk gipsum dapat dilihat pada Gambar 5. 


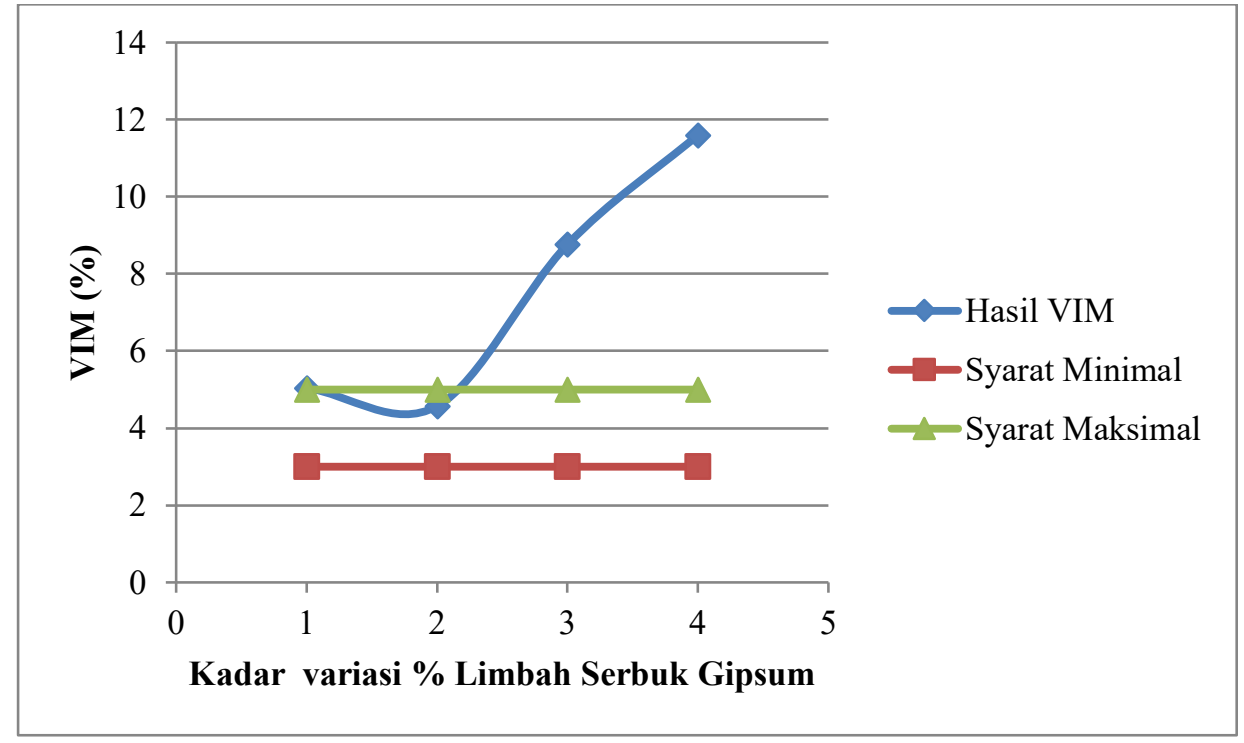

Gambar 5. Hubungan (VIM) dengan limbah serbuk gypsum

Dari Gambar grafik diatas menunjukkan bahwa dengan penambahan limbah sebuk gipsum sebagai bahan pengganti filler mempengarui hasil dari VIM . Dimana semakin banyak variasi yang ditambahkan maka akan semakin tinggi nilai VIM. Dari data diatas nilai VIM pada kadar limbah serbuk gipsum 7\% yaitu 4,57\% sehingga memenuhi ketentuan Standart Spesifikasi Umum Divisi 6 : Perkerasan Aspal dengan syarat 3\% - 5\%, sedangkan pada variasi kadar limbah serbuk gipsum 8\% dan 9\% mengalami peningkatan hingga melebihi batas ketentuan Standart Spesifikasi Umum Divisi 6 : Perkerasan Aspal.

Kadar aspal, pemadatan dan gradasi agregat sangat mempengaruhi hasil VIM. Nilai VIM dapat menunjukkan kekedapan pada perkerasan. Nilai VIM yang rendah mengakibatkan kekakuan pada campuran sedangkan nilai VIM yang tinggi menunjukkan banyaknya rongga pada campuran sehingga tidak kedap air dan udara yang dapat menyebabkan kerusakan pada lapisan perkerasan.

\section{Tinjauan penggunaan limbah karbit terhadap kelelehan (flow)}

Flow adalah nilai yang di tunjukkan oleh jarum alroji pada alat Marshall dan sudah dalam satuan mm. Hasil pengujian Flow pada aspal AC-WC dengan penggunaan limbah serbuk gipsum sebagai bahan pengganti filler secara umum memperlihatkan peningkatan dan penurunan pada nilai Flow. Adapun hubungan antara Flow dengan limbah serbuk gipsum dapat dilihat pada Gambar 6.

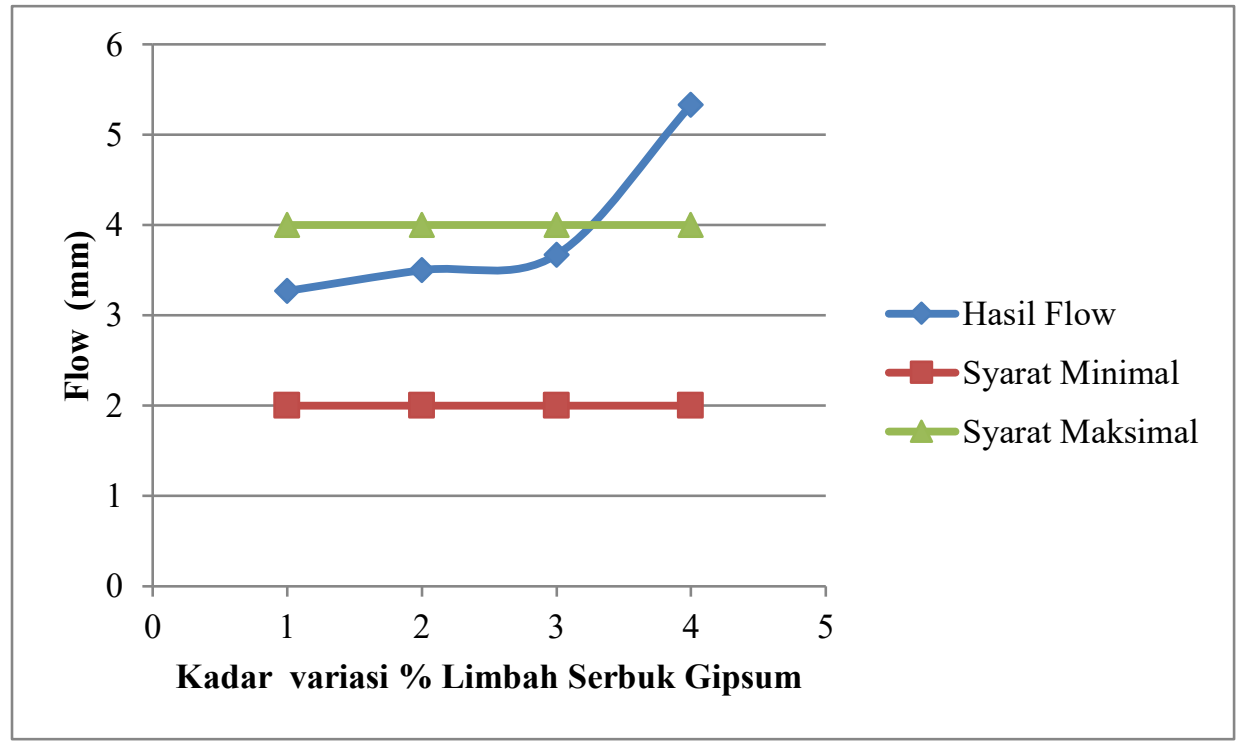

Gambar 6. Hubungan flow dengan limbah serbuk gypsum 
Dari Gambar grafik diatas menunjukkan bahwa dengan penambahan limbah sebuk gipsum sebagai bahan pengganti filler mempengarui hasil dari flow. Dimana pada kadar limbah serbuk gipsum 7\% dan 8\% telah memenuhi ketentuan Standart Spesifikasi Umum Divisi 6 : Perkerasan Aspal dengan syarat $2-4 \mathrm{~mm}$. sedangkan pada variasi kadar limbah serbuk gipsum 9\% tidak memenuhi ketentuan Standart Spesifikasi Umum Divisi 6 : Perkerasan Aspal karena hasil pengujiannya telah melebihi batas persyaratan yang telah ditetapkan.

Nilai flow sangat di pengaruhi oleh kadar aspal. Campuran yang memilik nilai kelelehan tinggi dan nilai stabilitas rendah maka perkerasan mempunyai sifat plastis. Sebaliknya jika nilai kelelehan rendah dan nilai stabilitas tinggi maka perkerasan mempunyai sifat getas.

\section{Tinjauan penggunaan limbah karbit terhadap Marshall Quotient (MQ)}

Marshall Quotient (MQ) adalah hasil pembagian nilai stabilitas dan nilai flow sehingga sangat berpengaruh pada nilai flexible terhadap keretakan. Hasil pengujian MQ pada aspal AC-WC dengan penggunaan limbah serbuk gipsum sebagai bahan pengganti filler secara umum memperlihatkan peningkatan dan penurunan pada nilai MQ. Adapun hubungan antara MQ dengan limbah serbuk gipsum dapat dilihat pada Gambar 7.

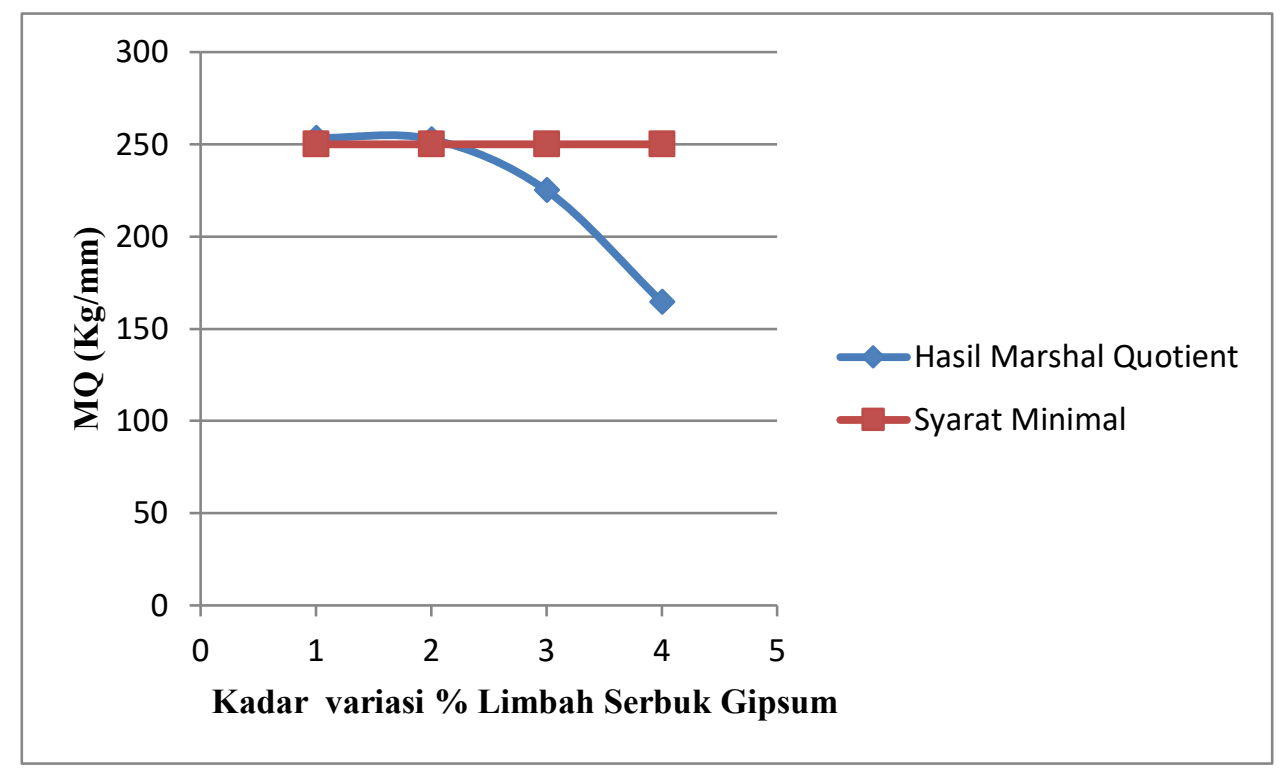

Gambar 7. Hubungan $M Q$ dengan limbah serbuk gypsum

Dari Gambar grafik diatas menunjukkan bahwa dengan penambahan limbah sebuk gipsum sebagai bahan pengganti filler mempengarui hasil dari marshall Quotient (MQ) . Dimana semakin bertambah variasi limbah serbuk gypsum maka semakin menurun nilai MQ - nya. Dari data diatas nilai MQ tertinggi adalah pada variasi 7\% yaitu mencapai $252.72 \mathrm{Kg} / \mathrm{mm}$ hasil ini telah memenuhi ketentuan Standart Spesifikasi Umum Divisi 6 : Perkerasan Aspal yitu dengan ketetapan minimal $250 \mathrm{Kg} / \mathrm{mm}$. sedangkan pada variasi limbah serbuk gipsum $8 \%$ dan $9 \%$ tidak memenuhi persyaratan karena nilai MQ nya titak memenuhi persyaratan ketentuan Standart Spesifikasi Umum Divisi 6 : Perkerasan Aspal.

Nilai MQ yang terlalu tinggi dapat mengakibatkan campuran bersifat kaku dan tidak flaxibel sehingga perkerasan akan mengalami retak-retak. Sebaliknua jika MQ nilainya terlalu kecil makaa dapat mengakibatkan campuran yang bersifat flexible sehingga mudah mengalamideformasi pada saat perkerasan menerima beban lalu lintas. Nilai MQ tergantung pada besarnya nilai stabilitas dan nilai flow.

\section{KESIMPULAN DAN SARAN}

\section{Kesimpulan}

Dari hasil penelitian yang sudah dilakukan, penggunaan limbah serbuk Gypsum sebagai pengganti Filler pada campuran $(A C-W C)$ ternyata mempengaruhi hasil Marshall Properties. Variasi kadar Filler limbah serbuk Gypsum yang digunakan dalam campuran $(A C-W C)$ adalah 7\%, 8\%, dan 9\%. Dimana variasi limbah serbuk Gypsum yang telah memenuhi spesifikasi adalah pada variasi $7 \%$ yaitu nilai Stabilitasnya mengalami peningkatan $870,95 \mathrm{Kg}$ dibandingkan dengan nilai Stabilitas pada variasi $0 \%$ atau normal yaitu dengan nilai $813,76 \mathrm{Kg}$. Nilai $V F W A$ mengalami kenaikan yaitu $88,81 \%$ dari variasi $0 \%$ atau normal dengan nilai $86,40 \%$. Nilai Flow mengalami kenaikan 
yaitu 3,50 mm dari nilai Flow pada variasi 0\% atau normal yaitu 3,27\% dan Marshall Quotient (MQ) juga mengalami kenaikan dengan nilai $252,72 \mathrm{~kg} / \mathrm{mm}$ di bandingkan pada variasi $0 \%$ atau normal yaitu $253,41 \mathrm{Kg} / \mathrm{mm}$. Namun pada nilai $V M A$ terjadi penurunan yaitu $19,35 \%$ dari pada variasi $0 \%$ atau normal dengan nilai $19,75 \%$ dan nilai VIM juga mengalami penurunan yaitu 4,57\% dibandingkan pada variasi $0 \%$ atau normal dengan nilai 5,04\%. Meskipun nilai $V M A$ dan VIM mengalami penurunan dari variasi $0 \%$ atau normal akan tetapi hasil tersebut masih memenuhi spesifikasi umum 2010 devisi 6.

\section{Saran}

1. Penggunaan metode eksperimental pada penelitian ini hendaknya dikembangkan lebih lanjut guna untuk mengetahui hasil yang lebih baik lagi.

2. Pada saat pengujian di laboratorium di perlukkan persiapan yang matang sehingga memudahkan peneliti untuk melaksanakan penelitian.

3. Pada saat pengukuran bahan dan pembacaan data pada alat pengujian sangat di perlukan ketelitian agar mendapatkan data yang valid.

\section{DAFTAR PUSTAKA}

Auditia, B. A., \& Rendih. (2018). Pengaruh Penggunaan Bubuk Gypsum Sebagai Filler Dalam Campuran Aspal. Teknik Dan Ilmu Komputer, 07(26), 149-155.

BSN. (2008a). SNI 1969-2008. cara uji berat jenis dan penyerapan air agregat kasar. Badan Standardisasi Nasional. Jakarta.

BSN. (2008b). SNI 1970-2008. cara Uji Berat Jenis Dan Penyerapan Air Agregat Halus. Badan Standardisasi Nasional. Jakarta.

BSN. (2011a). SNI 2433-2011. Cara Pengujian Titik Nyala dan Titik Bakar. Badan Standardisasi Nasional. Jakarta.

BSN. (2011b). SNI 2434-2011. Cara Pengujian Titik Lembek Aspal. Badan Standardisasi Nasional. Jakarta.

BSN. (2011c). SNI 2441-2011 Cara Pengujian Berat Jenis Aspal. Badan Standardisasi Nasional. Jakarta.

BSN. (2011d). SNI 2456-2011. Cara Pengujian Penetrasi Aspal. Badan Standardisasi Nasional. Jakarta.

Christanto Andi, \& Ibnu, W. (2005). Perbandingan Antara Penggunaan Filler Limbah Gipsum dan Semen Porland Pada Karakteristik Marshall dan Nilai Kohesi Campuran beton Aspal. Universitas Islam Indonesia.

Hardiyatmo, H. C. (2015). PEMELIHARAAN JALAN RAYA (Gadjah Mada University Press (ed.); kedua). Agustus 2015.

Hardiyatmo, H. C. (2017). Perencanaan Perkerasan Jalan dan Penyelidikan Tanah (Gadjah Mada University Press (ed.); ketiga). Juni 2017.

Hartantyo, S. D., \& Hermanto, B. (2019). p ISSN 2579-4620 e ISSN 2581-0855 PENGARUH PENGGUNAAN KRIKIL MANTUP SEBAGAI BAHAN p ISSN 2579-4620 e ISSN 2581-0855. 3(2), 140-149.

Hasmiati, \& Nurakhmad, A. L. O. M. (2014). Mix Design Asphalt Concrete Wearing Course (Ac-Wc) Dengan Menggunakan Fly Ash Batu Bara. 4(1), 133-144.

Kementerian Pekerjaan Umum dan Perumahan Rakyat; Direktorat Jenderal Bina Marga. (2010). Spesifikasi Umum 2010 (Revisi 3) Divisi 6 (pp. 1-89).

Soehartono. (2015). Teknologi Aspal dan Penggunaannya Dalam Konstruksi Perkerasan Jalan (Maya (ed.)). ANDI

Subono, V. P. (2011). Karakteristik Marshall Campuran Asphalt Concrete (AC) dengan Bahan Pengisi (Filler) Abu Vulkanik Gunung Merapi. 